\title{
Marrabenta, uma produção periférica de nacionalidade moçambicana
}

Vércio Gonçalves Conceição ${ }^{1}$

\section{RESUMO}

Este artigo propõe apresentar resultados preliminares do estágio doutoral desenvolvido na cidade de Maputo - Moçambique e visa abordar a marrabenta como uma elaboração popular da moçambicanidade, um símbolo nacional. Para isso, se utilizará dos depoimentos dos "narradores da marrabenta" - artistas da cena musical, intelectuais e atores da cultura moçambicana -, como principal vetor para pensar a questão posta. Depoimentos de artistas da marrabenta - tais como Antonio Marcos, Aniano Tamele, Djilon Djindji e Wazimbo -, a par de elaborações teóricas de moçambicanos como Andrè Feres (2011), José Luís Cabaço (2009), Natan Aquino (2016) e Rui Guerra Laranjeira (2010) -, além da brasileira Jacimara Souza Santana (2013), estão sendo utilizados aqui como forma de contribuição para a construção do argumento.

PALAVRAS-CHAVE: Marrabenta. Moçambique. Moçambicanidade. Nacionalidade. Periférica.

\section{RESUMEN}

Este artículo presenta los resultados preliminares de la pasantía del Doctorado, desarrollado en la ciudad de Maputo - Mozambique, el cual tiene como objetivo mostrar la marrabenta como una elaboración popular característica de la mozambicanidad, un símbolo nacional. Para tal fin, se utilizarán los testimonios de los "narradores de la marrabenta" - artistas de la escena musical, actores e intelectuales de la cultura mozambicana - como principal vector para abordar la cuestión planteada. Testimonios de artistas - tales como Antonio Marcos, Aniano Tamele, Djilon Djindji y Wazimbo conjuntamente con elaboraciones teóricas de mozambicanos de la talla de André Feres (2011), José Luís Cabaço (2009), Natan Aquino (2016) y Rui Guerra Laranjeira (2010) - además de la brasileña Jacimara Souza Santana (2013) serán utilizados aquí, como forma de contribuir a la construcción del leitmotiv.

PALABRAS-CLAVE: Marrabenta. Mozambique. Mozambicanidad. Nacionalidad. Periférica.

\section{Primeiras palavras}

Neste artigo, me proponho a pensar sobre a marrabenta como uma elaboração popular dentro da nacionalidade moçambicana. Avalio esse processo como algo que teria sido forjado

\footnotetext{
1 Universidade Federal da Bahia Campus Ondina (UFBA), Salvador, Bahia, Brasil. E-mail: verciagoncalvez10@yahoo.com.br.
} 
e mantido tanto à revelia do Estado Colonial - quando surge entre as décadas de 1930 e 1940 -, quanto à revelia do Estado Nacional - considerando desde o período que tange aos primórdios de uma organização em torno de ideias independentistas e nacionalistas, representadas nos princípios da FRELIMO - Frente de Libertação de Moçambique, ainda como movimento de libertação, mas também como partido que se instituiu após a independência e que, ainda hoje, ininterruptamente, se mantém à frente do país.

Esse estudo faz parte da minha pesquisa de tese de doutoramento e, nessa etapa, busco refletir junto a alguns personagens que compõem a cena da marrabenta, ou mesmo de autores da cultura popular ou da Academia, a quem passo a chamar de "narradores da marrabenta" e com os quais desenvolvo a interlocução. Pessoas que pude acessar e que generosamente forneceram suas narrativas, permitindo registro e documentação para essa pesquisa, quando estive na cidade de Maputo, entre os meses de janeiro e março do ano de 2020, a realizar estágio doutoral e, consequentemente, pesquisa de campo, junto à Faculdade de Música da Universidade Eduardo Mondlane, sob a supervisão do co-orientador da pesquisa, o professor Dr. Eduardo Lichuge.

Algumas questões me acompanharam quando segui rumo à Moçambique e, ao menos, uma delas, trago para tentar desenvolver nessa discussão: Por que a marrabenta não foi alçada a símbolo nacional pelo discurso oficial? Parto dessa questão, uma vez que, mesmo sem evocação direta, essa foi uma reflexão presente em, praticamente, todas as narrativas que consegui registrar. Para além dos depoimentos dos "narradores da marrabenta", quero compartilhar com o leitor ou apenas "pensar alto" sobre algo que pude observar, mesmo em curto espaço de tempo, qual seja: um possível silenciamento ou talvez uma tentativa de apagamento da marrabenta como ritmo nacional.

Essa é uma questão que me chama a atenção - também e pela ausência - na literatura de cunho nacionalista e independentista da década de 1960 e em dois livros de memória², em que se pode, a partir de duas histórias individuais, conhecer sobre a vida do moçambicano na periferia da, então, Lourenço Marques, no período colonial e primeiros momentos após a

\footnotetext{
${ }^{2}$ O livro Memórias (1985), de Raul Bernardo Honwana e Mahanyela - A Vida na Periferia da Grande Cidade (2018), de Nely Honwana. Ambos os autorxs são pais do escritor Luís Bernardo Honwana, que escreveu o emblemático Nós Matámos o Cão-Tinhoso (1964), livro de narrativas que flagram cenas da situação colonial vivida pelos moçambicanos, denunciando a violência e o racismo dos portugueses. Ouso a dizer que a família Honwana teve um papel importante na gestação da luta junto à FRELIMO. Pelos relatos de memória e pelo texto literário, é possível perceber certo comprometimento com as questões políticas e culturais que pairavam sobre Moçambique no período colonial. Devo mencionar que a obra de L. B. Honwana foi o mote para minha pesquisa de Mestrado, que resultou na dissertação intitulada Nós matamos o cão-tinhoso: anticolonialismos, projetos de nação e protagonismos de (novos) homens moçambicanos.
}

R. Articul.const.saber, 2021, v.6: e66221 
independência. Estou falando, afinal, de registros ficcionalistas e memorialistas importantes para se apreciar a construção da nação moçambicana, em que o discurso sobre as culturas e línguas locais (nacionais) nascem exercendo um papel preponderante. No entanto, a marrabenta não é flagrada, nem mesmo en passant, nesses arquivos que podem ser considerados como importantes documentos da memória cultural de Moçambique.

De outro modo, diversos agentes da história moçambicana - hegemônicos ou nãohegemônicos - produzem narrativas que recolocam a marrabenta como expressão musical nacional. Agentes que, ora são representantes legítimos, protagonistas da história da marrabenta no país; ora são outros, como agentes financeiros que, apropriando-se dessa manifestação na condição de símbolo cultural, a vinculam a suas marcas em peças publicitárias em busca de atrair o mercado consumidor com o apelo midiático de 'produto nacional'.

Em princípio, não posso deixar de registrar que o contato com os estudantes de graduação e pós-graduação, advindos dos países africanos de língua portuguesa pode ser considerado um ganho na passagem, anterior à Moçambique, por Portugal, junto à Universidade de Coimbra. Lá, fui recebido pela Profa. Dra. Maria Paula Meneses, que atuou como orientadora de minha pesquisa, através do CES - Centro de Estudos Sociais, um contato imprescindível para o que consegui redelinear em meu estudo. Essa experiência em terras portuguesas me possibilitou, na prática, pensar sobre a negritude: ser negro no Brasil tem o mesmo significado de ser negro nos países africanos? Como é ser negro (brasileiros, bissauguineenses, moçambicanos, angolanos, cabo-verdianos, santomenses) em Portugal? Também me fez olhar para as questões raciais de forma mais complexa.

Nesse sentido, os diálogos com esses estudantes/professores/pesquisadores foram basilares, me levando ao entendimento de que é preciso ler as negritudes considerando seus contextos políticos e culturais. Compreender isso foi um dos pressupostos fundamentais para iniciar minha incursão em Maputo, visto que me preparou para lá chegar com a escuta mais sensível ao contexto local. Foi difícil em alguns momentos, já que a nossa formação ocidental nos condicionou à prática de definir teorias, categorias, pontos de vista sobre o Outro, especialmente quando esse Outro é/está em África. No entanto, aqui, faço um esforço reflexivo no encontro com os moçambicanos iniciando com uma apresentação teórica moçambicana, na intenção de contextualizar a marrabenta para o leitor. Do segundo momento em diante, a partir dos relatos que registrei desses "narradores da marrabenta", me ponho a 
pensar junto com eles sobre a marrabenta, considerando sua origem periférica e as relações raciais na cena em que o citado movimento musical se desenvolve. Por último, a ideia é discutir sobre a noção do nacional que orbita a marrabenta, não sendo, entretanto, um consenso em todos os setores da sociedade.

\section{A Marrabenta}

Considerando-se o contexto brasileiro de pesquisas sobre Moçambique, pouco se sabe sobre a marrabenta. Por isso, acho válida uma rápida contextualização da trajetória do ritmo melhor dizendo, movimento artístico-musical ${ }^{3}$ - moçambicano, afinal, algumas noções básicas se fazem necessárias para que o leitor acompanhe a reflexão proposta aqui e, desse modo, recorro à linguagem acadêmica, na sua forma de comunicar, embora priorize acessar o conhecimento por uma chave de leitura centrada no olhar moçambicano, confrontando estudos realizados por pesquisadores, tanto da academia, como aqueles que produzem o saber, dito popular, como os poetas, músicos e artistas em geral de Moçambique.

Começo com o estudo do moçambicano Rui Guerra Laranjeira $(2010)^{4}$, para quem a marrabenta "é o principal ritmo musical de Moçambique", que nasce da miscigenação entre os ritmos levados por pessoas oriundas da zona rural, alocadas nas periferias da então Lourenço Marques, hoje Maputo, com a presença de elementos da música ocidental. Laranjeira defende que o ritmo se popularizou na década de 1950, a partir dos conjuntos Djambu, Hulla-Hoope e Harmonia, mas, explica que o processo de estilização dessa música moçambicana se deu através das Associações de Naturais, pois tais associações defendiam a cultura e a identidade cultural dos africanos no período colonial, que eram marcados pela supressão dos feixes identitários notadamente "nativos". Assim sendo, a

[...] Associação Africana (AA) e o Centro Associativo dos Negros da Província de Moçambique (CANPM), vão contribuir para o resgate da identidade e cultura moçambicana apesar da obrigatoriedade de cantar e dançar músicas e ritmos portugueses entre 1912 a 1975, quando da Independência. Para a adopção e promoção da cultura moçambicana, destaque-se o trabalho de José Craveirinha

\footnotetext{
${ }^{3}$ Isso porque, é praticamente um consenso nas falas dos depoentes de que a marrabenta é um movimento de estilização e urbanização da música da zona rural, o que seria, trocando em miúdos, a execução de ritmos tradicionais com o que tinha de mais moderno para a época, um set list ocidental, formado por guitarras, baterias, teclado e instrumentos de sopro.

${ }^{4}$ Texto extraído de site, sem paginação. O mesmo se aplica a todas as citações literais feitas, ao longo do artigo, sem número de página.
} 
(Associação Africana) e Samuel Dabula Nkumbula (Centro Associativo dos Negros) que, devido à consciência política e cultural, contribuem para a adopção e promoção de ritmos, músicas e danças africanas nas associações (LARANJEIRA, 2010).

Conforme Laranjeira, a marrabenta surge na região que corresponde a Maputo (ainda Lourenço Marques), Gaza e Inhabane, ao sul de Moçambique, entre os anos 1930 e 1940, mas não tinha esse nome ainda. André Feres (2011), no entanto, defende que o ritmo tenha nascido na década de 1950 "a partir das guitarras improvisadas com latões de azeite [...] e linhas de pesca". Mas ambos os autores moçambicanos concordam com a ideia de que o ritmo tenha surgido no subúrbio de Lourenço Marques, oriundo da fusão entre os ritmos locais Zukuta, Xigombela e Magika, sob a influência das músicas ocidentais - a qual, segundo Feres, chegavam a partir de emigrantes retornados da África do Sul e das poucas rádios que existiam na década de 1950, através das quais já havia uma circulação do blues, do jazz e do cha-cha-cha, ritmos que acabaram por fazer parte da estilização da marrabenta. Natan Aquino (2016) contribui para esse diálogo, informando que:

\begin{abstract}
A história do ritmo que virou referência da identidade moçambicana é cheia de possíveis leituras. A origem, os instrumentos, os passos e até mesmo o nome ganham diferentes versões no país e não há uma mais verdadeira que a outra. A Marrabenta é um pouco de todas. A Marrabenta é por si só a foz de diferentes culturas. É uma dança que traduz muitos em outros múltiplos. E, por isso, defender uma só verdade seria impossível. Marrabenta é uma verdade plural, assim como sua história, que começa quando Maputo era ainda Lourenço Marques, em meados do começo do século XX (AQUINO, 2016).
\end{abstract}

O autor explica, ainda: “os aglomerados populacionais eram centros de recepção de diferentes culturas, que por sua vez contavam com sua própria língua, tradições e ritmos" (AQUINO, 2016). Para ele, o contexto originário da marrabenta, justamente, firma-se no diálogo entre essas culturas, atravessado por temas cotidianos: casamentos, momentos históricos moçambicanos e "de quando em quando" críticas ao sistema colonial, chamando a atenção do governo português que, logo, tratava de considerar como música subversiva. André Feres (2011), a esse respeito, pontua que a marrabenta é um ritmo acompanhado por uma dança sincopada e sensual e que, já por esse motivo, ratificava a motivação da censura lusitana. Quando os artistas se lançavam a criar letras com críticas ao sistema colonial, por conseguinte, eram deportados para a África do Sul.

Para Laranjeira (2016), a incorporação da marrabenta nas associações figurou como um “culminar do processo de 'Regresso às Origens', iniciado na década de 1940 por vários 
pensadores e dirigentes africanos", que visavam, através das várias linguagens artísticas, afirmar valores e identidades africanas. Conforme expõe, os grupos de marrabenta que atuavam nesse período “contribuíram [...] na difusão da música ligeira entre a população africana, para a divulgação dos ritmos moçambicanos e a sua penetração no seio da população colonial" da década de 1950.

Os três autores moçambicanos - Laranjeira (2010), Feres (2011) e Aquino (2016) consideram que a presença da guitarra elétrica permitiu a estilização da marrabenta, de modo a promover uma reelaboração das identificações sociais e das várias manifestações da cultura popular e que, num movimento proliferador, contribuiu para que a música estabelecesse "novas identidades para aquela nação ainda em estágio embrionário" (LARANJEIRA, 2010). Outro fator citado por eles foi a incorporação da marrabenta à congregação da vanguarda artística moçambicana. Junto aos nomes dos intelectuais da literatura, tais como Craveirinha, Noémia de Souza, Bertina Lopes e Luís Bernardo Honwana, os grupos de marrabenta buscavam "construir a latente nação, pregando o retorno às origens africanas e o repúdio ao colonialismo português" (AQUINO, 2011).

José Luís Cabaço (2009) faz uma reflexão sobre essa população que se formou no subúrbio de Lourenço Marques, a quem chama de "grupos sociais periurbanos", constituindo o africano da periferia que, "mantendo suas cosmogonias e falando quase exclusivamente a própria língua, se encontrava distante de sua comunidade, desenquadrado das relações hierárquicas, dos vínculos tradicionais", ou seja, das práticas dos espaços rurais (CABAÇO, 2009, p.139). Segundo o autor, a economia colonial, em estágio crescente, provocou a urbanização do campo, mas não conseguiu manter o controle sobre esses camponeses, que migraram de uma estrutura tradicionalista para um habitat moderno e ocidental, pelo que se percebe, sem nenhum planejamento. Para ele,

[a] "reestruturação" sociocultural e psicológica que o indivíduo periurbano vivia traduzia-se em diversificadas estratégias de sobrevivência, procurando retirar o melhor - e o mais útil para si - do contraditório cotidiano em que se encontrava inserido. A hostilidade do meio e das condições com que se confrontava estimulava a identificação com outros indivíduos em situação análoga e o surgimento de laços de solidariedade de novo tipo (CABAÇO, 2009, p.140).

Como resultado disso, conforme explica, eles criavam códigos e ritos flexíveis de interpretação e de adaptação aos contextos do momento, adaptando-se ora aos comportamentos da sociedade branca, ora aos comportamentos do campo, para tirar vantagens 
ou para se defender. Com isso, o autor pontua que esses, num processo de síntese, foram se apropriando do próprio destino, "tornava-se sujeito de um processo, o de sobrevivência, fazia cultura e começava a retomar, das mãos do colono, a iniciativa do próprio futuro como indivíduo e como grupo" (CABAÇO, 2009, p.140).

Movendo-se, inconscientemente, em nome da sobrevivência, dentro da perversa sociedade colonial que os excluía da cidadania e discriminava-os racialmente, este grupo iniciou um processo de subversão do poder colonial. Cabaço (2009) vai dizer que os periurbanos, não se submetendo ao dualismo da sociedade colonial - europeu ou tradicional agenciaram um grande poder de transformação por intermédio do qual despontaram muitos militantes nacionalistas, não obstante a presença de agentes e informadores das forças repressivas do poder colonial. Afinal de contas, não tinha como ser diferente. Conforme exposto antes, foi um processo inconsciente e em nome da sobrevivência, portanto informal, como pontua:

\begin{abstract}
O processo de aprendizagem se fazia habitualmente em grupos, na maioria dos casos informais, no seio dos quais trocavam-se experiências de vida, imaginavam-se expedientes de autodefesa, traçavam-se planos de entreajuda. Dessas discussões despontavam um primeiro esboço de interpretação da realidade em que eles se encontravam imersos, a consciência da diferença e das desigualdades, e se forjavam estratégias identitárias sedimentadas na própria condição de africanos, de dominados politicamente, de segregados racialmente e de marginalizados economicamente. Tal sentimento de autodefesa esteve na base da constituição de formas elementares de organização colectiva estruturadas que iam dos temidos grupos mabandidos até associações de mútuo auxílio e agremiações religiosas (CABAÇO, 2009, p.142143).
\end{abstract}

Segundo Cabaço, as agremiações religiosas eram estruturadas a partir do sentimento de africanidade. Buscavam suas referências na Bíblia ou num "pan-africanismo rudimentar", muitas vezes em ambos, pela conexão com a diáspora americana, tornando-os conectados também com organizações internacionais, o que gerava preocupação ao poder colonial, deixando-o em estado de vigilância. Essas agremiações religiosas, junto aos ideais panafricanistas e protonacionalistas, alimentavam os "ressentimentos por humilhações e sofrimentos padecidos na engrenagem da máquina colonial" e era também o que impulsionava camponeses a imaginarem “desejos e ambições até aí impossíveis” (CABAÇO, 2009, p.148).

Jacimara Souza Santana (2013, p. 5) também faz referências às agremiações religiosas e defende que "as igrejas africanas cumpriram um importante papel na propaganda e 
conscientização por uma luta anticolonialista", pois, segundo ela, os africanos fundaram organizações religiosas para atender a população negra africana, algo bastante significativo no sul de Moçambique. A pesquisadora brasileira chama a atenção para o fato de o panafricanismo e a luta nacionalista serem, geralmente, referenciados como movimentos formados por intelectuais, instruídos na Europa e na América, desconsiderando a coparticipação popular. Ela defende que a construção desse discurso não teria se efetivado senão a partir da interação entre intelectuais e pessoas da população, já que "o conhecimento destes intelectuais não esteve desagregado das realidades locais de suas comunidades" (SANTANA, 2013, p. 2). Ela, inclusive, pontua que, na década de 1950,

\footnotetext{
Com a reconfiguração internacional da luta por independência na África e o impedimento de formar partidos políticos ou outras organizações para estes fins pelo regime colonial, as associações [...] atuaram como espaços clandestinos de organização política fundadas em Moçambique e colônias vizinhas (SANTANA, 2013, p.101).
}

A autora conclui que o discurso nacionalista adquiriu interpretações distintas do discurso divulgado pelos intelectuais. Segundo ela, na periferia, esse discurso foi adequado às realidades locais, mas o imperativo político pela independência do colonialismo também era propagado.

\section{A marrabenta, a periferia e as relações raciais}

Com as informações da seção anterior, saí do Brasil, rumo à Moçambique, pleno de "quase certezas" sobre a marrabenta. Na verdade, incorria no erro do qual me alertou a professora Dra. Maria Paula Meneses: fazia uma leitura da música e da periferia de Maputo com o olhar carregado da realidade brasileira, soteropolitana, a qual conheço de perto. Tudo o que tinha lido sobre a marrabenta era muito pouco. Além do livro do moçambicano Rui Laranjeira, apenas tinha feito uma compilação de textos muito econômicos, retirados de alguns (raros) sites, pois no Brasil não há muito conhecimento produzido sobre a música moçambicana em questão. Desde então, eu já possuía algum entendimento do contexto histórico sobre o qual tenho voltado minha atenção, desde a pesquisa de Mestrado - período colonial moçambicano -, mas acabara projetando demasiadamente as tensões raciais da realidade brasileira na realidade moçambicana. 
Maria Paula não quis me entregar uma resposta pronta, mas alertou-me de que estivesse atento ao contexto moçambicano, em que as disputas se dão muito mais pelas questões de classe e não pelas diferenças raciais. Do mesmo modo, avisou-me da dificuldade que poderia ter em encontrar depoentes da marrabenta, que ela considerava uma música geracional. Ainda em Portugal, pude conhecer um jovem estudante moçambicano da graduação, que confirmou o que foi dito por minha orientadora estrangeira: ele nunca tinha ouvido falar na marrabenta e não conhecia os nomes dos principais expoentes - tais como Fany Mpfumo e Dilon Djindji, por exemplo. Isso me causou certa desestabilização quanto à viabilidade da investigação, pois achei que minha pesquisa corria algum risco na execução das entrevistas de campo.

Temi chegar a Maputo e não encontrar os "narradores da marrabenta". Tive receio de a marrabenta não mais existir no imaginário local. Entretanto, ainda estava movido pela curiosidade que toca todo pesquisador e pensei que poderia conhecer os arquivos históricos/museus que me levariam a um contato com essa música periférica da Maputo, então, Lourenço Marques, no período colonial. Assim fiz e, em janeiro de 2020, cheguei à Maputo, com uma ligeira impressão de estar em Salvador, no Brasil. Impressão que foi sendo substituída pelas observações da diferença, o que foi positivo, porque olhar para a diferença, me preparou para o conhecimento de tudo aquilo que Maputo estava a me oferecer, o que passo a dividir, nesse momento, com o (a/e) leitor (a/e).

No que se refere à realização das entrevistas, acho importante pontuar que a coleta do material superou a expectativa inicial. Através dos contatos fornecidos pela professora Maria Paula, pude estabelecer uma rede de depoentes significativamente relevante. Uma vez em Maputo, contei com a generosidade de alguns pesquisadores/as ${ }^{5}$ que, de pronto, se dispuseram a dar o apoio necessário para acessar meus personagens da cena da marrabenta. Ao todo, foram 11 depoimentos ${ }^{6}$ dos sujeitos que cito a seguir: Dilon Djindji, António Marcos, Wazimbo, Aniano Tamele, Roberto Chitzondson, Rufus Mucavele, Marilio Wane, Daniel Vilanculo (Danito), Terencio Tovela, Ivan Laranjeira e Rui Laranjeira. Essas pessoas representam vozes com autoridade para narrar a marrabenta, uma vez que se trata de músicos,

\footnotetext{
${ }^{5}$ Os pesquisadorxs Me.Tirso Sitoe (antropólogo, gestor da Bloco 4 Foundation - Research in Activism), Dra. Alda Costa e Dr. Edson Uthui (Diretora e pesquisador da Secretaria de Cultura da Universidade Eduardo Mondlane, respectivamente) foram muito importantes para que eu desse os primeiros passos em Maputo.

6 Os depoimentos foram gravados em imagem e áudio, a fim de atender ao objetivo de produzir um documentário a partir desse material, como forma de devolutiva à comunidade moçambicana, especialmente, em consideração aos participantes da pesquisa, pertencentes às gerações mais antigas.
}

R. Articul.const.saber, 2021, v.6: e66221 
cantores e compositores, além de pesquisadores, cujas produções são voltadas para a música surgida na periferia, tendo o bairro da Mafalala como um dos principais palcos de elaboração. Desse modo, as falas registradas desses protagonistas vieram a colaborar substantivamente para a construção do argumento de minha tese.

Com Dilon Djindji, António Marcos, Wazimbo e Aniano Tamele (filho de Euzébio Tamele, o lendário Zeburane, como é conhecido pelos músicos de Maputo), pude ter acesso a uma narrativa que remonta um olhar de dentro e da época da colonização. Dilon Djindji, aparentemente displicente, acaba por evidenciar as estratégias que alguns músicos da marrabenta utilizavam, na época, para lidar com, ou autodefender-se (CABAÇO, 2009, p.140) das opressões do sistema colonial e dispor de alguns benefícios, tais como tocar no centro da colônia.

Ao ser questionado se conseguia levar sua música para qualquer lugar da cidade de Lourenço Marques, ele comenta: "Em qualquer parte... Tocava no cinema, na cidade, em Xipamanine... Tocávamos, Lisboa Matavele, mesmo João Domingos, mesmo Djambo 70". Quando mencionamos a PIDE - Polícia Internacional de Defesa do Estado e a censura, ele diz que "a marrabenta não é nada! É a desvirginação das meninas..., mas as pessoas estavam a pensar coisas muito ao contrário...”. Sobre esse ‘contrário' que as pessoas estavam a pensar, quando o questiono, fugidiamente, ele diz "não sei... Por que que estava a dar problema o nome marrabenta? Pensavam muita coisa, as pessoas da cidade...". A dissimulação estratégica, que percebo na fala de Dilon Djindji, fica mais evidenciada na passagem em que se apresenta como "amigo dos portugueses". Ele diz que foi chefe do gabinete do engenheiro Evaristo, no Estado de Salazar, no tempo colonial e diz que não só ele era amigo dos portugueses, mas outros cantores, como Francisco Marracuene e Lisboa Mutavele também. Mas o que denuncia mesmo esse jogo é quando, nesse mesmo contexto, Djindji (2020) passa a falar sobre sua prisão:

Eu, quando fui preso em 1968, na BO, então, quando foi julgado...então, antes da decisão do tempo de ficar na cadeia, me tiraram. Os meus filhos foram falar ao governador João Moraes que o nosso pai, cantor, está na BO. Até João Moraes foi explicar a Samora Machel, quando foi explicar a Samora Machel, ele disse "não... Djindji não pode ficar na cadeia... Aquele é grande cantor, pra fazer as pessoas brincar. Ele, então, no dia do julgamento, veio ser chamado quando estava em casa... até me tirar da cadeia...voltei pra casa... até hoje, nunca fui chamado... não podem me chamar agora...". 
Nesse momento, percebe-se a complexidade presente na sua fala, cuja interpretação requer certa cautela, pois ele se diz amigo dos portugueses, mas vai preso e quem vai interferir na sua soltura é Samora Machel, ninguém mais, ninguém menos, do que um membro e principal quadro da FRELIMO, tornando-se, inclusive, o primeiro presidente de Moçambique. O motivo que leva Dilon Djindji à prisão, então, faz com que se pergunte até onde vai o nível de amizade dele com o sistema colonial:

\begin{abstract}
Eu estava a criar as cooperativas lá na machamba, então, o administrador, no tempo, uma pessoa não podia realizar uma reunião com as pessoas, sem o administrador ter conhecimento, da administração. Eu escrevi a carta, mandei para entregar a carta a administração, pedindo autorização para eu realizar essa reunião com as pessoas, para eu conseguir... pra gente realizar essa reunião, pra gente cultivar machamba. $\mathrm{O}$ mixadoro ${ }^{7}$ não foi lá, adiamos... Escrevi a segunda carta. A segunda carta, depois de 1 mês, não foi. Escrevi a terceira carta, depois de dois meses, o administrador não foi lá. Então, eu realizei a reunião com a população que eu tinha lá embaixo, pra gente começar a fazer as lavouras. Pra gente conseguir começar a produzir as lavouras, pra gente plantar arroz... o administrador não foi... Então, há uma pessoa que foi na segunda-feira ao administrador dizer "Ei, Djilon Djinji realizou reunião na machamba lá, ontem. Então o administrador mandou 9 milicianos... vieram me buscar aqui, aqui já, eu estava a morar aqui. 1h da madrugada, bateu à porta... Minha mulher não quis ir, eu foi atender... quando saiu são os milicianos, militares e pergunto "o que é que vocês querem?" "O administrador mandou te chamar pra ir lá". "1h da madrugada, vocês me mandam chamar a esta hora? Onde ele está?". Os milicianos disseram "está em casa. Disse pra gente vir te buscar". Eu me vesti e fui com eles. Quando chegamos lá, disseram "ah...é pra entrar no comando". Entrei no comando. Disseram "epa, ele saiu agora, mais outra vez, mas ele disse que há de vir ou você pode voltar amanhã de manhã". Já era 2:30h... Fiquei lá na esquadra. A tal que estava na esquadra disse "você não pode dormir aqui fora, vai dormir lá dentro". Eu disse "não... lá dentro? São os prisioneiros que estão lá dentro. Vou ficar aqui fora e fiquei aqui fora até às $6 \mathrm{~h}$ da manhã... 7h... 7:30h... (DJINDJI, 2020).
\end{abstract}

Pela primeira vez, no contexto do desenvolvimento desta pesquisa, percebo a partir das falas ouvidas - considerando os depoimentos de Djinlon Djindji e Antonio Marcos como se dá a questão das relações raciais em Moçambique no período colonial e dentro da cena da marrabenta. Tais relatos corroboram com textos como os de Samuel Matusse que escreve sobre a obra de Fany Mpfumo, assim como os depoimentos de Rui Laranjeira e de alguns outros "narradores da marrabenta" (que nessa ocasião ainda não serão trazidos), vão demonstrar a diferença dos acessos entre os cantores/bandas de marrabenta, a partir do quesito raça/classe social entre os filhos da terra reconhecidos como mulatos e pretos. Segundo esses registros, os mulatos estavam se apresentando nos espaços da cidade mais ao centro, na medida em que os pretos, como bem nos fala António Marcos, só podiam tocar nos bairros

\footnotetext{
${ }^{7}$ Administrador, na língua ronga.
} 
periféricos e, ainda assim, na Mafalala não era todo preto que tocava. Tocar na "zona de cimento" era um privilégio que ele não possuía, por ser preto:

\begin{abstract}
Era difícil tocar nos cabarés, essas coisas de luxo... eu não entrava, porque cantava em "língua do cão" ... era o que eles diziam: não pode cantar em "língua do cão" [uêuêuêuê]... era pra cães aquilo... Então, os assimilados tinha que escutar aquela língua deles, fado, essas coisas... então, eu não tinha acesso... mas acabei tendo acesso quando tínhamos a Rádio Clube de Moçambique, atual Rádio Moçambique, onde havia divulgação de música moçambicana. Portanto, consegui furar ali na década de 1970, pra poder gravar ali (ANTÓNIO MARCOS, 2020).
\end{abstract}

Ao narrar sobre a frequência dos brancos nos bairros indígenas (era assim que se referiam, no período colonial, aos bairros da periferia, onde habitavam os indígenas, mas também os assimilados e os mulatos, bem como árabes e indianos), Antônio Marcos explica o seguinte:

\begin{abstract}
É assim: os pretos podiam circular na cidade de dia, mas à noite a cidade era para os brancos, é assim. De dia, o preto pudesse circular na cidade, ou ia trabalhar ou ia fazer limpeza..., mas de noite o preto não tinha o direito de ir na cidade. Ia fazer o quê na cidade? Então, o branco é que saía da cidade, para apanhar os pretos e as pretas cá fora [...] O branco, olha, ouve cá: o preto toca sua parte onde está aqui, mas não vai ao encontro de um branco que está ali. O branco vem e diz: "muito bem, pretinho", dá um escudo, muitas vezes não dá, né? Vinha cuspir e eu tinha que aceitar tudo (ANTÓNIO MARCOS, 2020).
\end{abstract}

Pelas duas narrativas, nota-se uma diferença: enquanto Djilon Djindji informa que, junto a nomes como Lisboa Mutavele, Francisco Marracuene, João Domingos, entre outros, podiam se apresentar na cidade; Antonio Marcos só tocava na periferia e só conseguiu gravar na rádio na década de 1970, momento em que se considera já um afrouxamento da força colonialista, devido ao trabalho da FRELIMO. Da mesma forma: Djilon Djindji foi preso por estar envolvido em atividade não permitida pela administração, como apresentado anteriormente e, ainda assim, teve espaço para negociação, como se pode perceber em sua narrativa. A situação para os pretos é diferente, como explica Antônio Marcos, em termos de análise da atuação da PIDE e a censura colonial: “Aqui no mato, você toca no mato, eles estão ali dentro, se eles sentirem que você está a tocar o contrário, você desaparece ali. Se, onde eles forem, tem a pesca, aquilo que eles apanharem, que dá para pescar, é aquilo que eles carregam". E, assim, se percebe a diferença no uso da violência para o trato com o preto.

Os irmãos Ivan e Rui Laranjeira apresentam um olhar mais histórico, a partir do bairro da Mafalala. Ambos trabalham na gestão do Museu da Mafalala e Rui escreveu um livro 
sobre a marrabenta, Marrabenta: evolução e estilização 1950-2002 (2014). Na fala de ambos, a Mafalala aparece como espaço de negociação/mediação cultural. Ivan, tanto no tour $^{8}$ que ele faz com os visitantes do museu pelo bairro, quanto no seu depoimento, expõe que a Mafalala é um não-lugar, um espaço entre o rural e o urbano, onde sujeito moçambicano esteve em contato com a tradição, mas também com outras dinâmicas. Para Ivan Laranjeira, a marrabenta é uma música urbana, mas que se encontra nesse não-lugar. Algo que seu irmão, Rui Laranjeira, vai pontuar na perspectiva racial. Segundo Rui, a marrabenta é uma música considerada como de negro, sendo que no período colonial, para levar adiante o discurso da metrópole - que fazia apologia à mestiçagem -, foi dada maior evidência a grupos como a Orquestra João Domingos, formada majoritariamente por mulatos.

Preciso ressaltar que, após estar em Moçambique e ouvir os moçambicanos, foi necessário repensar minhas certezas sobre as questões raciais. Notei que as categorias "preto" e "mulato"/"mestiço" aparecem nas falas dos entrevistados de forma muito espontânea. Observei que há a manutenção dessas categorias criadas pelo sistema colonial. Ainda assim, mesmo diante das falas e de situações que presenciei e que traziam as questões raciais para o centro, sinto que é ainda prematuro elaborar uma análise de forma assertiva, fechada e conclusiva sobre o racismo ou a negritude ${ }^{9}$ no contexto moçambicano. Essas são questões para futuro aprofundamento na tese.

Senti, no entanto, a necessidade de propor uma outra discussão sobre negritude, porque ainda é muito comum confundirmos o lugar social "negro", do qual nos fala Milton Santos $^{10}$, que funciona como categoria de análise para nós brasileiros (também para os estadunidenses) - englobando uma diversidade de pessoas não-brancas com variados traços negroides -, como se essa fosse uma realidade também para os países africanos. Percebi, em Maputo, que essa categoria de análise não se adequa da mesma forma como a utilizamos no Brasil, mesmo quando interseccionamos com o marcador de classe social, pois, se a pobreza em Moçambique tem uma cor e é a mesma cor da pobreza brasileira, existe, por outro lado, também uma elite política, econômica e intelectual "preta"/ "mulata".

Desse modo, não há como recorrer a uma única categoria de análise fechada, como se o Brasil fosse a moldura para se pensar raça/racismo nos países africanos. Especialmente, na interlocução mantida com os filósofos Severino Ngoenha e o brasileiro Eduardo Oliveira (este

\footnotetext{
${ }^{8}$ Severino Ngoenha me levou a fazer o tour, oportunizando conhecer o museu e me apresentar a Ivan Laranjeira.

${ }^{9}$ Destaco que, aqui, o uso do termo tem relação com a consciência de ser negro e do lugar social do negro.

${ }^{10}$ Ser negro no Brasil Hoje.
} 
último se encontrava em Maputo no mesmo período, como professor visitante, nas Universidades Técnica/Pedagógica/Eduardo Mondlane), fui levado a perceber que a situação racial em Maputo é bastante complexa e bem diferente do Brasil, portanto decidi por - em minha análise - não fazer comparações ou estabelecer hierarquias sobre elaborações de negritude nos dois países. Acredito que será produtivo para os estudos africanos aqui no contexto brasileiro, uma vez que amplia as noções sobre o tema a partir de outra realidade, a realidade de Maputo, por exemplo.

\section{3. "A marrabenta não é nacional, porque é tocada apenas no sul do país"}

As falas de Wazimbo e Aniano Tamele (sobre a música do seu pai, Zeburane) trazem uma perspectiva da marrabenta como um espaço para se pensar a moçambicanidade, seja ela como vetor de apresentação das tradições ou da modernidade. Os dois artistas são de gerações mais novas que as de Djilon Djindji e Antonio Marcos, mas também viveram parte do tempo colonial e seus depoimentos são importantes para pensarmos a marrabenta, principalmente em seu caráter como símbolo da nação moçambicana.

Wazimbo traz a influência da Rádio Clube Moçambique para tratar da formação musical do moçambicano, que acessava muito mais às produções dos EUA e do Brasil, que a música local. Ele fixa como ponto de análise os primeiros anos da década 1970, período em que estava tocando o seu trabalho e já possuía algum reconhecimento. São os últimos momentos da colonização em Moçambique, momento ao qual ele se refere como de abertura. Segundo Wazimbo, era comum os artistas e agrupamentos musicais moçambicanos desse período tocarem a "música ligeira" ou "música estilizada", que era a música urbana, ou seja, as músicas tradicionais, tocadas com uma instrumentação ocidental. Desse movimento de urbanização dos ritmos que eram veiculados no interior, esses artistas passaram a executar também um repertório mais influenciado pelas rádios, portanto músicas de outros países, principalmente, o Rock e o Samba. Mas ele traz uma experiência vivida em Angola que o fez repensar o seu fazer artístico e que eu reproduzo aqui para refletirmos a questão nacional na música moçambicana:

Wazimbo: Eu, com já certo nome na praça, sou convidado a assinar um contrato com um clube noturno em Angola, na ilha de Luanda. Então fui pr'ali com minha banda e, modéstia à parte, fizemos muito sucesso, porque também estávamos a levar um estilo de música totalmente diferente que os angolanos estavam habituados.

R. Articul.const.saber, 2021, v.6: e66221 
Vércio: E era um ritmo específico daqui?

Wazimbo: Não, não. Naquela altura, ainda tocávamos um pouco de tudo, ok? Eu lembro-me de uma abordagem do empresário do coisa... porque o que é que aconteceu nos primeiros, na primeira semana? $\mathrm{O}$ que aconteceu na primeira semana é que os angolanos, na altura - eu estou falando de 1972. Os angolanos, o que eu pude ver e confirmar, é que eles já se tinham afirmado como angolanos, como nacionalistas e defendiam a sua cultura. Tanto assim que tudo o que eles veiculavam - em festas de família ou festas populares, em grandes festividades - era com base na música nacional. Enquanto que eu, na qualidade de moçambicano, naquela época, ainda não tinha esta afirmação, porque a segregação era muito forte. A Polícia Internacional de Defesa do Estado, que se chamava PIDE, apertava você e vigiavam o conteúdo das canções que nós fazíamos. Porque, naquela altura, era uma época em que se fazia canções de crítica... de crítica ao sistema governativo na altura... Então, não eram só portugueses que estavam nessa corporação, não é? Também tinha lá moçambicanos. Os moçambicanos, maior parte deles, estava lá pra produzir seu "ganha-pão", não porque estivessem contra os ideais da revolução, entendeu? Mas, então, nós tocávamos um pouco de tudo naquele net clap. Tocávamos desde música americana, música brasileira, música cubana e etc. etc. Então, o que é que a primeira coisa que reparamos, é que, quando nós tocássemos, as pessoas ficavam quietinhas, sentadinhas, a tomar o seu copo e não se fazia uma pista de dança. Estávamos a trabalhar, em simultâneo, com uma banda angolana. Quando nós cedêssemos o palco, para um intervalo, entravam os angolanos, quando entravam os angolanos - $\hat{\mathrm{e}}$ pá! - enchiam as pistas. Então, pra nós, à primeira vista, a interpretação que nós demos foi "bom, esses são da casa...". O produtor angolano, durante o nosso intervalo, veio ao camarim. Veio ao camarim e fez-nos essa pergunta:

- Vocês não tocam música de vossa terra, música moçambicana, não tocam?

- Oh, pá, isso é o nosso forte! Claro que tocamos, sim, senhor!

- É, pá, experimenta, porque tu tens reparado que quando vocês sobem ao palco, embaixo são poucos os casais que se fazem pista?

- Também já reparamos nisso, mas estávamos a pensar que os outros tinham mais audiência, porque são da casa...

- Não. Experimenta tocar música de vossa terra, música de Moçambique.

No dia seguinte, preparamo-nos nesse sentindo e à noitinha, quando chegamos ali, $50 \%$ da música que tocávamos, que passamos a tocar era música de Moçambique [...] de Fany Mpfumo, etc. e etc., eis que a pista, que aquilo deu resultado. A pista começou a ganhar corpo e, pá, todo mundo ia lá dançar. Então, no intervalo, o homem disse:

- Já viram como pegou? Eu não vos disse?

Pronto, a partir daquele dia, pá, a malta começou a ensaiar mais músicas moçambicanas, mais músicas moçambicanas e, ao mesmo tempo, começamos a ganhar a noção da nossa moçambicanidade. Começamos a ganhar a noção que nós somos moçambicanos. Daí, pá, "é por este caminho que nós temos que ir". A partir daí, terminou o contrato, eu voltei pra Moçambique, já eram músicas mesmo, eram aquelas músicas todas que nós conhecíamos e aquelas que nós íamos escrevendo, porque também componho. Então, desde dessa altura até os dias de hoje, ganhei é... o meu nome ganhou uma dimensão, que não é só Moçambique, é Europa, é Brasil... eu já estive no Brasil, no programa Esquenta, há uns 4 ou 5 anos atrás, levando a marrabenta pra lá. 
Esse relato de Wazimbo nos traz alguns elementos para pensarmos a construção de uma moçambicanidade a partir da música. Da dificuldade que era construir esse imaginário em termos de sonoridade, em termos de discurso, em termos de valorização das sonoridades locais. Um primeiro elemento é algo que, aliás, está presente na narrativa de Antonio Marcos, apresentado anteriormente: a censura e a ação da PIDE retardando e mesmo impedindo a construção de uma nacionalidade, que em nada se assemelha à ideia de nação à qual Portugal ainda se agarrava de todas as formas, estando Moçambique como território ultramarino português. Por isso, as rádios locais (segundo elemento), seguiam trabalhando ativamente na construção de uma identidade musical que desprestigiava a produção musical local. Aniano Tamele faz uma reflexão sobre o tema e nos apresenta uma contextualização interessante da década de 1970, a partir da marrabenta:

Ao longo de minha infância, desde 1976, vivi muito ligado a ouvir muita música em casa. Ouvia muita música moçambicana na rádio, que a Rádio de Moçambique transmitia naquela altura, que era a única estação emissora. Não havia ainda televisão, não havia outras rádios comerciais, como agora temos e, nesse percurso, tinha que ouvir, finalmente, a nossa rádio, que tocava muitos ritmos moçambicanos, mas com alguma incidência pra marrabenta. Por que a marrabenta? A marrabenta é um ritmo que se desenvolve muito na zona sul do país, sobretudo na capital do país, que é onde se tem maior facilidade de criação de bandas, maior possibilidade de as pessoas se juntarem, quando tinham possibilidade de comprarem instrumentos ou ir buscá-los na África do Sul. E é nesse processo que a marrabenta começa a enraizarse, mas eu fui procurando perceber: a marrabenta é o quê, é um ritmo? É um estilo de dança? E fui observando que o nome "marrabenta" surge inserido no ritmo que se tocava. Há muitas interpretações, mas uma delas é muito usada em algumas canções da época. Marrecuane dizia "arrebenta, fio!" Esse arrebentar é que eles tocavam até arrebentar a corda. É o que dá origem a esse "arrebentar"..., mas depois evolui para uma fase em que é preciso dançar até arrebentar... dançar até cair... Esse dançar até cair também vai dando origem ao nome marrabenta. Normalmente, esses nomes, nunca se encontra uma explicação científica, pelo fato de que, na época, ninguém se preocupou em escrever isto, então são fontes que nós vamos ouvindo, fontes orais e da vivência própria que vamos encontrando e que nos levam a pôr a marrabenta através de tudo isso. Ora, em algum momento, eu fui percebendo a marrabenta era mais um ritmo de Maputo do que de outras províncias, porque em Gaza, por exemplo, Euzébio Johane Tamele, que é meu pai; o Francisco Marrecuane, que foi o segundo artista moçambicano a gravar disco e o Feliciano Gomes, que foi o primeiro artista a gravar disco, na década de 1940, não usaram muito o termo marrabenta, usaram mais magika. E magika, se for a repararem, é um ritmo de [...] dança que não tem absolutamente nada a ver com a marrabenta. $O$ que tem a ver e que deve acontecer, em minha opinião, é que Moçambique precisa ter uma identidade, da mesma forma que o Brasil, que tem o samba, apesar de haver outros ritmos. Da mesma forma que a Jamaica, que apesar de ter outros ritmos, fala-se muito do reggae. Então, Moçambique está a procurar um ritmo de identidade e, por causa de que há muita similitude entre a magika e a marrabenta, e a marrabenta é a que mais se popularizou a partir de Maputo, vai para o exterior a partir de Maputo, esse nome terminou por ser utilizado até para denominar os festivais de música, desses tipos que acontecem aqui (TAMELE, 2020). 
Assim como pode ser percebido na fala de Wazimbo, a preocupação por pensar a marrabenta como um ritmo que faz circular a ideia de música nacional moçambicana surge também no relato de Aniano Tamele. O interessante é notar que ambos não deixam de tocar na importância das outras músicas produzidas em outros territórios moçambicanos, para além da capital, Maputo, mas acentuam a força que a marrabenta possui - talvez por ser um ritmo que surge do encontro de outros ritmos moçambicanos e da estilização com instrumentos ocidentais, em contexto periférico, mas urbano - para se tornar um ritmo moçambicano com identidade nacional.

A reflexão posta por Aniano Tamele e Wazimbo começou a fazer sentido para mim, ao buscar os serviços do BCI - Banco Comercial de Investimento (para efetuar o pagamento da taxa cobrada pelo Arquivo Histórico ao acessar seu acervo) e observo a presença da marrabenta nas peças de publicidade do banco sendo evocada como elemento de nacionalidade moçambicana, com a explícita intenção de conferir, também, ao banco o caráter de instituição nacional, conforme pode ser apreciado nas peças publicitárias abaixo:

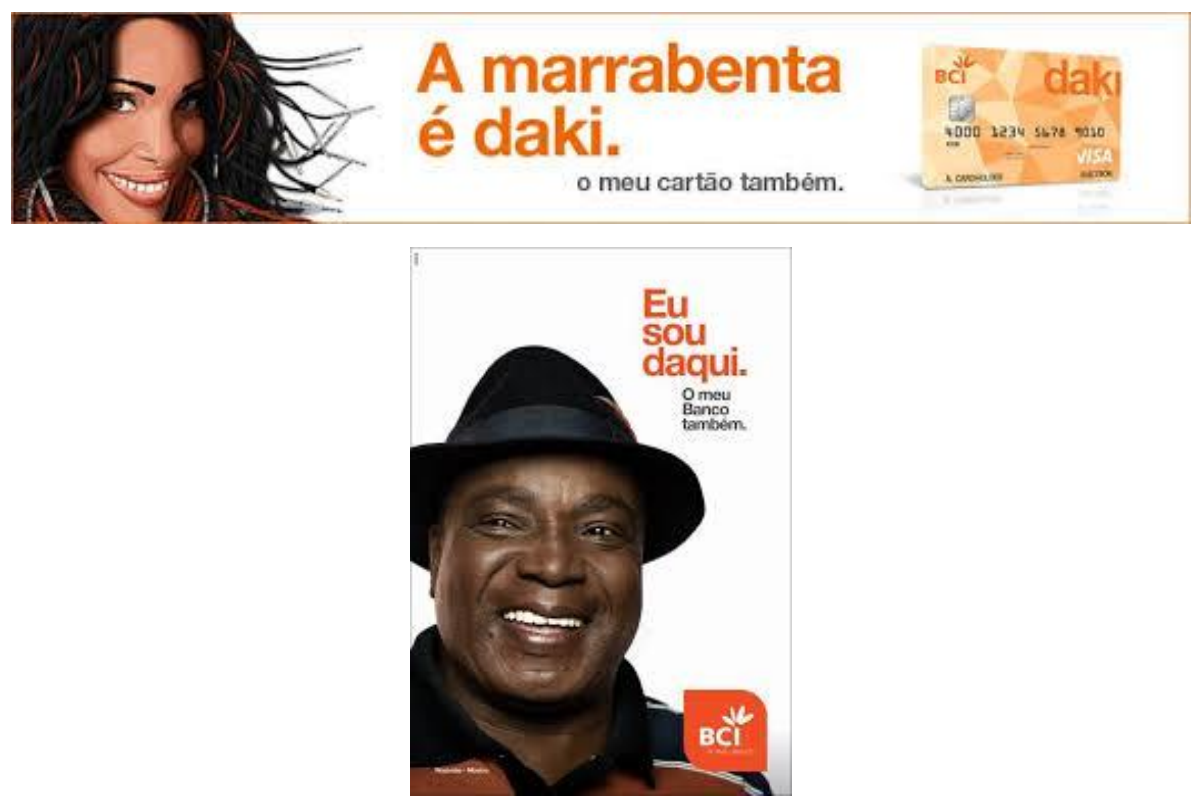

Fonte das imagens:

http://www.29rba.abant.org.br/resources/anais/1/1401754447_ARQUIVO_GT034_Eusoudaqui,eusoudaqui_FFT.pdf

No primeiro card, tem-se a propaganda do cartão de crédito daki, num perfeito jogo de palavras e ideias, firmando a mensagem de que, assim como a marrabenta, o cartão também é daqui, no caso de Moçambique. No segundo card, com a imagem de um moçambicano - o astro da marrabenta, Wazimbo -, afirmando "Eu sou daqui, o meu banco também é", percebe- 
se a mesma mensagem de autenticação da nacionalização da instituição. Como se vê, a marrabenta foi o elemento do qual o BCI lançou mão como símbolo de nacionalidade, de moçambicanidade.

A publicidade do banco BCI vai na contramão do que me disseram quase todos os entrevistados: a marrabenta não havia sido lançada pela FRELIMO como símbolo nacional por apenas pertencer a Maputo, por ser uma música praticada apenas ao sul do país. Se é ou se não é nacional, se passa despercebida por alguns setores sociais, uma coisa eu percebi: a marrabenta está muito presente, ao menos em Maputo, reconhecida ou legitimada, inclusive, por uma das maiores entidades financeiras ali presentes. Além disso, convivi muito com o ritmo. Das muitas vezes que fui à Associação dos Músicos, na Jam Session que ocorre às quartas-feiras, o som que mais se tocou, por diferentes músicos, foi, indiscutivelmente, a marrabenta.

\section{Considerações finais}

A título de finalização desse texto, apresento aqui alguns pontos de observação que estão longe de serem considerações finais e se aproximam do que me sinto à vontade a considerar como primeiras impressões desse contato com Maputo, com a cena da marrabenta, com a recepção da marrabenta pelos moçambicanos, habitantes de Maputo.

Então, para além das questões postas até aqui, algumas outras surgem e acredito serem importantes para o desenvolvimento da tese, mais adiante. Algo que me causou surpresa, no contexto do campo, tem relação com o caráter geracional da marrabenta. A hipótese levantada, quando ainda me encontrava em Portugal, foi refutada. Tive a sorte de chegar à cidade um mês antes do Festival da Marrabenta, que ocorreu entre os dias $1^{\circ}$ e 4 de fevereiro de 2020. O que pude presenciar no evento foi completamente diferente da ideia de que a marrabenta era geracional, supostamente circunscrita aos mais velhos que a conheciam e a apreciavam. Pelo contrário, pude notar no festival que, além de trazer em sua grade, artistas de diferentes gerações, havia uma plateia diversificada com muitos jovens e crianças. Junto aos mais velhos, esses desfrutaram das apresentações com o mesmo envolvimento.

No primeiro dia do evento, no Campo da Costa do Sol, pude assistir a uma programação que, na parte da tarde, apresentou crianças que cantavam e dançavam a marrabenta. No período da noite, o festival teve o palco ocupado por nomes como Orquestra 
Djambo 70, Dilon Djindji e Banda Kakana. Durante a tarde, fui surpreendido pelas crianças que, não só conheciam a marrabenta, como cantavam e dançavam. À noite, alguns aspectos me chamaram a atenção:

1) as apresentações da Orquestra Djambo 70 e de Dilon Djindji foram acompanhadas por um público bem diversificado - crianças, jovens e adultos de diferentes idades -, que acompanhavam os cantores, cantando as letras em changana, ronga ou uma terceira língua, resultado da mistura das línguas mencionadas; além disso, os jovens dançavam fazendo coreografias dessas músicas;

2) a Banda Kakana, que foi apresentada como uma banda de estilo variado, além de cantar algumas músicas que traziam em seu arranjo elementos da marrabenta, cantou uma música da banda que em seu refrão afirmava "não deixa morrer a marrabenta", uma música cantada por uma nova geração de artistas, em português, o que denota a ideia de "atualização" da tradição, como lembra Stuart Hall ${ }^{11}$ (2011). Até aqui, só havia conhecido letras da marrabenta em chagana/ronga...

Adiante, outras questões foram surgindo quando retomei a reflexão geracional: por que o jovem moçambicano, estudante de Coimbra não conhecia nada sobre a marrabenta, uma vez que jovens da sua mesma geração e até mais novos estavam no festival a cantar e a dançar a marrabenta junto aos seus mais velhos? Passei a aventar que o fato de desconhecer, ou enunciar desconhecer a marrabenta poderia ter relação com o recorte de classe. Será que é preciso negar a marrabenta para ser reconhecido como pertencente a uma das camadas das classes mais privilegiadas da sociedade? $\mathrm{Ou}$, de fato, os jovens circunscritos a determinados lugares sociais na cidade de Maputo não acessam tal manifestação e ignoram a sua presença atual como importante expressão cultural moçambicana? Essas são questões a serem problematizadas na pesquisa até a sua conclusão.

Uma última observação, que não posso deixar de registrar, tem relação com a questão de gênero. Dos nomes indicados para coleta de depoimentos, o único nome feminino que aparece é o da cantora Mingas. Estando no Festival da Marrabenta, vi que a banda Djambo 70 possui duas pessoas nos vocais, um cantor mais jovem e Cecília, que está na banda desde o seu início. O organizador do festival, Lito, tentou promover uma reunião com esses artistas

\footnotetext{
${ }^{11}$ A Identidade Cultural na Pós-Modernidade.
} 
mais velhos da cena da marrabenta, inclusive com o Sr. Moisés da Conceição que completou 100 anos em 2020 e foi o homenageado do evento. Mas, infelizmente não houve tempo para realizar o encontro, o contexto da pandemia que se instaurou no globo e das medidas de controle subsequentes, me obrigou a retornar ao Brasil antes do período previsto.

Com o plano de trabalho interrompido pela pandemia, houve alguns prejuízos à pesquisa. Além do encontro prometido por Lito, havia uma entrevista marcada com Calane da Silva, Hortênsio Langa e outras por confirmar, como a de Filimone Meigos (chegamos a nos conhecer e nos encontrar por duas vezes, em situações em que o mesmo não tinha disponibilidade para dar seu depoimento). Também tive o processo interrompido nas articulações que fiz a partir da Dra. Alda Costa que me pôs em contato com o doutor em Música, o professor Edson Uthui, sendo de suma importância para a articulação e o acesso às personalidades mais antigas da marrabenta, as quais entrevistei: Dilon Djindji (94 anos) e António Marcos (68 anos).

No entanto, ambos iriam colaborar me indicando outros nomes e fazendo a mediação da comunicação, mas, como dito anteriormente, foi preciso adiantar o retorno ao Brasil muito antes do previsto, cuja estada estava prevista até o dia 10 de abril de 2020. Moçambique estava por fechar as fronteiras, o que acabou por acontecer dois ou três dias após minha viagem de retorno. Portugal, infelizmente, já havia fechado, o que inviabilizou meu retorno à Coimbra. Só me restou, nesse caso, voltar para o Brasil e aguardar nova oportunidade de continuar a pesquisa, regressando à Coimbra e à Maputo.

\section{Referências}

AQUINO, Natan. Arrebenta marrabenta: da velha guarda ao contemporâneo. Disponível em: <http://www.afreaka.com.br/arrebenta-marrabenta/>. Acessado em dezembro de 2016.

CABAÇO, José Luís. Moçambique: identidade, colonialismo e libertação. São Paulo: Ed. Unesp, 2009.

CONCEIÇÃO, Vércia Gonçalves. Dissertação. Nós Matamos o Cão-Tinhoso: anticolonialismos, projetos de nação e protagonismos de (novos) homens moçambicanos. Dissertação (Mestrado - Letras - Programa de Pós-Graduação em Literatura e Cultura) -Universidade Federal da Bahia, Instituto de Letras, 2016. 
FERES, André. Marrabenta: música para suas cadeiras! Disponível em: <https://penegrinho.wordpress.com/2011/04/04/marrabenta-musica-para-suas-cadeiras/>. Acessado em dezembro de 2016.

HALL, Stuart. A identidade cultural na pós-modernidade. Tradução Tomaz Tadeu da Silva e Guacira Lopes Louro. 11. ed. Rio de Janeiro: DP\&A, 2006.

HONWANA, Luís Bernardo. Nós matamos o cão-tinhoso. São Paulo: Editora Ática, 1980.

HONWANA, Nely. Mahanyela - a vida na periferia da grande cidade. Maputo: Marimbique, 2018.

HONWANA, Raul. Memórias. Maputo: Marimbique, 2010.

LARANJEIRA, Rui Guerra. Marrabenta: evolução e estilização 1950-2002. Disponível em: <http://www.buala.org/pt/palcos/marrabenta-evolucao-e-estilizacao-1950-2002>. Acessado em dezembro de 2016.

SANTANA, Jacimara Souza. "O branco não tem panela para nos cozer": eco popular dos movimentos pan-africano e nacionalista no sul de Moçambique. Sankofa, Revista de História da África e de Estudos da Diáspora Africana, Ano VI, No XI, Agosto/2013, p.96114. Disponível em:

<http://www.revistas.usp.br/sankofa/article/view/88913>. Acessado em dezembro de 2016.

SANTOS, Milton. Ser negro no Brasil Hoje. In: Folha de São Paulo, 07 de maio de 2000. Disponível em: <https://www1.folha.uol.com.br/fsp/mais/fs0705200007.htm>. Acessado em abril de 2017.

Submetido em 16 de outubro de 2020.

Aceito em 25 de janeiro de 2021.

Publicado em 02 de fevereiro de 2021. 